Ankara Üniversitesi

SBF Dergisi,

Cilt 66, No. 4, 2011, s. 67 - 100

\title{
IS THE GLOBAL FINANCIAL GRISIS A CRISIS OF ACADEMIC ECONOMICS AND ECONOMICS EDUCATION? A RESEARCH ON THE PERCEPTIONS OF TURKISH ECONOMISTS
}

\author{
Yrd. Doç. Dr. Metin Özdemir \\ Uludağ Üniversitesi \\ IïBF
}

\author{
Dr. Esra Gïler \\ Uludağ Üniversitesi \\ ïBF
}

\begin{abstract}
The global financial crisis has triggered considerable debate concerning economics as an academic discipline and the education of economists. This paper explores the relationship between the global financial crisis, mainstream economics and the future of economics education in the Turkish context. Using a questionnaire administered to academicians teaching economics in Turkish universities, we aim to determine their perceptions of the relationship between mainstream economics and the current crisis by using factor analysis. We determined that the academicians were of the opinion that mainstream economics played an important role in the occurrence of the crisis. Our study reveals that, it is necessary to develop more realistic models to be used in economics and to establish a more productive relationship with other social sciences such as history, sociology and politics. This development requires a framework for economics education with a more pluralistic orientation that allows for different theoretical frameworks.

Keywords: Global financial crisis, mainstream economics, economics education, role of economists in the crisis, factor analysis

Küresel Finansal Kriz, Akademik İktisadın ve İktisat Ĕ̈itiminin Krizi mi? Türk İktisatçıların Algılamaları Üzerine Bir Araştırma

\section{Özet}

Küresel finansal krizin, akademik bir disiplin olarak iktisat bilimi ve onun bir parçası olan iktisat eğitimi etrafinda gelişen önemli tartışmaları tetiklediği gözlenmektedir. Bu çalışma; küresel finansal kriz ile yerleşik iktisat arasındaki ilişkiyi Türkiye'deki üniversitelerde iktisat eğitimi veren akademisyenler üzerinden araştırmaktadır. Çalışmanın temel amacı, akademisyenlerin yerleşik iktisat ile küresel finansal kriz arasındaki ilişkiye yönelik algılamalarını belirlemek ve buradan hareketle iktisat bilimi ve eğitiminin geleceğine ilișkin çıkarımlarda bulunmaktır. Çalışmada uygulanan faktör analizinin sonuçları; akademisyenlerin, krizin ortaya çıkıșında yerleşik iktisadın önemli bir rol oynadığı düşüncesinde olduklarını ortaya koymuştur. Bulguların ortaya koyduğu sonuçlar, iktisat biliminin geleceğinde, daha gerçekçi modeller kullanması ve hakim paradigmanın diğer sosyal bilimlerle daha verimli bir ilişki tesis etmesi yönünde belirgin bir iradenin oluştuğunu ortaya koymaktadır. Açıktır ki böyle bir yönelim, farklı teorik çerçevelere yer veren daha çoğulcu bir iktisat eğitimini gerekli kılmaktadır.
\end{abstract} faktör analizi

Anahtar Sözcükler: Küresel finansal kriz, yerleşik iktisat, iktisat eğitimi, krizde iktisatçıların rolü, 


\section{Is the Financial Crisis, Crisis of Academic Economics and its Education? A Research on the Perceptions of Turkish Economists}

\section{Introduction}

The global financial crisis that began in the USA in August 2007 is considered to be a result of the period of growth and stability known as the Great Moderation experienced in the world economy in the early 2000s. While the current crisis has triggered significant debate concerning economic policy, the discussion of its effects on economics as an academic discipline and the education of economists have been neglected.

In the period before the crisis, it was often emphasised that there was, at least in the Anglo-Saxon world, a consensus between the economic policies being implemented and the theoretical nature of mainstream economics. This period of consensus ended with the current financial crisis. It has been observed that the crisis is a consequence of economic policies which is applied in a theoretical framework and models presented in mainstream economics ${ }^{1}$. As

\footnotetext{
${ }^{1}$ Although there is a widespread agreement in mainstream circles to explain the current crisis as a failure of economic policies implemented before, there are economists stressing that the crisis currently unfolding the world economy represents a crisis in the capitalist system itself. From the Marxist point of view, this is not just another massive credit crunch of the kind so familiar in the history of capitalism, but signals a new phase in the development of the contradictions of the system. Following the crisis of the 1890s, the Great Depression of the 1930s and the crisis of the 1970s; Marxist economists argue that the current crisis is the fourth major crisis of modern capitalism
} 
clearly indicated by J.M.Keynes (1936:383), "the ideas of economists and political philosophers, both when they are right and when they are wrong, are more powerful then is commonly understood... Practical men, who believe themselves to be quite exempt from any intellectual influences, are usually the slaves of some defunct economist... I am sure that the power of vested interests is vastly exaggerated compared with the gradual encroachment of ideas".

In this sense, the current crisis has become a crisis of academic economics. In contrast to other social sciences, economic theory is reduced to a single theoretical core, commonly termed neoclassical or mainstream economics which also dominates the economics' profession. It is therefore, possible to interpret the failure of academic economics to predict and explain the crisis as a severe weaknesses of the mainstream paradigm. As a matter of fact, the views of heterodox economists such as D.Colander et al. (2009), G.M. Hodgson (2009), T.Lawson (2009) and J.E.King (2009) relating to the crisis in mainstream economics can be seen to be shared within mainstream economics by economists such as P.Krugman (2009), B.Eichengreen (2009) and W Buiter (2009).

In this framework, this paper explores the relationship between the global financial crisis, mainstream economics and the future of economics education in the Turkish context. Using a questionnaire administered to academicians teaching economics in Turkish universities, we aim to determine the academicians' perceptions of the relationship between mainstream economics and the crisis to reveal its implications for the future of the science of economics and economics education. There have only been a few previous attempts to survey and quantify the views and opinions of Turkish economists concerning economics as an academic discipline and the state of economics education in Turkey by the Turkish Economic Association (1993; Uygur, 2005) and the Turkish Academy of Sciences (2007). Our study differs from the previous ones in an important aspect: we illustrate the perceptions of Turkish academic economists with regard to several aspects of the global financial crisis and explore its implications for the future after the crisis.

The study comprises five sections. Following the introduction, the second section explains the consensus among economists regarding the Great Moderation which ended with the crisis. In the third section, after presenting the position of mainstream economics in the face of social reality and other social sciences, we decipher the scientific unification of economics and finance 
before the crisis and its implications for economics as a social science. The two final sections of the study illustrate the questionnaire constructed based on the arguments discussed in the two preceding sections and the conclusions reached according to the evaluation of the obtained results.

\section{The Crisis and Economics}

An important differentiating characteristic of the current global financial crisis is that the appearance and dynamics of the crisis, and the criticisms directed at the discipline have been discussed by mainstream economists. The need for a new paradigm in the science of economics has become reality in a defined concept. Therefore, after the crisis, academic economics as a whole and the manner of its teaching were characterised by systemic crisis and failure (Colander et al., 2009:263). According to P.Krugman (2009), "Economics, as a field, got in trouble because economists were seduced by the vision of a perfect, frictionless market system".

In this context, the following section presents the consensus reached by economists before the crisis and the discussions around the role of mainstream economics.

\subsection{The Great Moderation and Consensus among Economists}

The theoretical-academic body of work noted long ago that there is a distinct difference between the theoretical framework of economists and the nature of the real world; therefore, the level to which applied economics affects policy is of particular interest. C.Goodhart (2009a:828) noted that a small group of economists (the majority being heterodox along with some postKeynesian economists) was uncomfortable with this paucity between theory and the real world.

In addition, since the beginning of the 2000s, it has been emphasised that the period of growth and price stability, defined as the Great Moderation (Bernanke, 2004), was due to the consistency between the theoretical framework and models of economists and the economic policies being applied (Stock and Watson, 2003:9-56;Goodfriend,2007:47-68). B.Eichengreen (2009) stated in this period that there was a belief that similar monetary policies applied at the global level created similar results: a decrease in the variability of output-inflation, a fall in interest rates and relative stability in the financial markets. Thus, G. Mankiw (2006:37) emphasised that the period before the crisis was of no practical importance to teaching the new generation of students about the economics of business cycles. 
As the theoretical structure explaining cyclical fluctuations and the formation of optimal policies developed over the period of the Great Moderation, New Neoclassical Synthesis (NNS) models emerged in response to the methodological consensus between New Classical Economics/Real Business Cycle Theory (NCE-RBCT) and New Keynesian Economics (Clarida, Gali, Gertler, 1999:1661-1707; Blanchard, 2009:209-228). In this context, NNS can be explained by a common reference to the microeconomic foundations of macroeconomics. It combines rational expectations and wageprice rigidity representing the foundation of an agreement between the two schools of macroeconomics (Goodfriend, 2002:166; Arestis, 2007:22). The empirical content of this methodological consensus is strengthened by Dynamic Stochastic General Equilibrium (DSGE) models (Zouache, 2004:103). DSGE models give policy makers the opportunity to evaluate the effects of monetary and fiscal policies under real and nominal rigidities, dependent on the optimisation behaviour of economic agents with rational expectations.

At the 1995 conference at which he was awarded the Nobel Prize for economics, R.E Lucas (1995:262) indicated that the consensus reached between economists in the period of the Great Moderation was a suitable process for the creation of real appropriate models. In this context, it can be seen that developing economic policies by means of NNS and DSGE models has become an appropriate technology to manage output, employment and the general level of prices.

\subsection{From the Collapse of Consensus to the Crisis in Academic Economics}

Aside from bringing the era known as the Great Moderation to an end, the crisis that began in the USA in August 2007 also engendered the collapse of the consensus between economists in the framework of NNS and DSGE models. B.Eichengreen (2009) stated, "We now know that much of what we thought was true was not. The Great Moderation was an illusion".

Initially, the emergence of the crisis was a surprise for most economists because it was thought to reveal a specific error in forecasting. After a time, questions about academic economics emerged. Paradoxically, the period before the crisis was crowned with a consensus between real world and mainstream economics; following the crisis, the theoretical-empirical foundations of this consensus became the object of serious criticism.

The assessment of these discussions and criticisms was triggered by a question from Queen Elizabeth II during her visit to the London School of Economics in November 2008, when she asked why economists had not 
foreseen the crisis ${ }^{2}$. The forum organised by the British Academy to find a response to this question expressed the view that the forecasting error arose from the failure to see the risks carried by the global financial system as a whole ${ }^{3}$.

In response to this view, a letter written by a group of heterodox economists including S. Dow, G. Hodgson, M. Sawyer and G. C. Harcourt, emphasised that in general, economists were responsible for not having foreseen the global financial crisis. As such, the economists in question believe that coupled with the insufficiency of the theoretical framework and models used by the mainstream economists, the crisis was also due in part to the narrowness of economics education and culture; economics had become a subbranch of mathematics with no room for cases in a real world historicalinstitutional dimensions ${ }^{4}$.

The two perspectives on whether economists and economics were responsible for failing to foresee the crisis have joined into debate. In this context, B.Eichengreen (2009) believes that the crisis arose due to economists having experienced a form of "problem of cognitive capture" with the principal-agent problem being related to the financial markets. When the problems of asymmetric information and moral hazards were taken into account, economists remained tied to the existing DSGE models and were blinded to developments appearing in the literature related to the financial markets.

If it is accepted that economists' view of the literature on financial markets was limited, it should be expected that after the crisis, the blinders would be removed and that the cognitive capture problem would be erased. However, even after this awakening no model was available with room for elements such as banks and financial intermediaries, heterogeneous agents and asymmetric information, principal-agent problems and coordination failures (Spaventa, 2009:3). Although DSGE models are based on the microfoundations of the goods and labour markets, they are given no room in the financial markets and the banking sector. Therefore in the framework of these models, the opportunity to evaluate the macroeconomic effects of financial (in) stability

\footnotetext{
${ }^{2}$ http://www.telegraph.co.uk/news/newstopics/theroyalfamily/3386353/The-Queenasks-why-no-one-saw-the-credit-crunch-coming.html.

${ }^{3}$ Full text of the letter sent to Queen Elizabeth II following the British Academy forum of 17.06.2009; http://www.feed-charity.org/revitalizing-economics-after-thecrash.htm.

${ }^{4}$ Full text of the letter sent to Queen Elizabeth II in response to the first letter; http://www.feed-charity.org/revitalizing-economics-after-the-crash.htm.
} 
Metin Özdemir-Esra Güler • Is the Global Financial Crisis a Crisis of Academic Economics and its Education? 73

is removed (Tovar, 2008:5). Furthermore, these models blinded the economics profession to the role of interactions between economic agents that have not been incorporated into models, such as institutional changes through deregulation and novel financial products (Colander et al., 2009:263-264).

This theoretical framework pushed economists to find a reason related to the economy's structural fundamentals to explain the global imbalances and bubbles of asset prices during the Great Moderation. Because the crisis occured in an environment of global price stability, it can be concluded that policymakers were misdirected by modern economics (Blanchflower, 2009:9; Kocherlakota, 2010:5-21). P.de Grauwe (2007) indicated that these models were designed to deal with inflation in the past and did not present a suitable or sufficient structure to deal with the dynamics of the current crisis. In addition, W.Buiter (2009) stated that in the consensus between NCE-RBCT and New Keynesian Economics, not only were questions such as insolvency and the liquidity crunch related to the financial markets not answered, but they were also not even asked. Consequently, Buiter evaluates the point arrived at with the NNS and DSGE models that considering the private and public cost, economics education and research over the last 30 years in Anglo-American universities has been a great waste of time.

Even before the crisis, a more striking evaluation of DSGE models was presented by R.E.Lucas (2004:23): "The problem is that the new theories, the theories embedded in general equilibrium dynamics of the sort that we know how to use pretty well now-there's a residue of things they don't let us think about. They don't let us think about the U.S. experience in the 1930s or about financial crises and their real consequences in Asia and Latin America. They don't let us think, I don't think, very well about Japan in the 1990s. We may be disillusioned with the Keynesian apparatus for thinking about these things, but it doesn't mean that this replacement apparatus can do it either. It can't'.

In this framework, the final point arrived at in the discussions around the NNS and DSGE models were that the global financial crisis was essentially an intellectual crisis and a failure of both mainstream economics and the economics profession. This perspective can be viewed not only from the perspective of mainstream economics' and the profession's inability to foresee the crisis, but also in consideration of their ethical responsibility for the failure to communicate the limitations and assumptions, even the dangers, of the models being implemented and proposed (Colander et al.,2009:264). 


\section{Mainstream Economics in the Face of Social Reality}

Despite being a product of a specific historical-social process like the other social sciences, by dealing with a priori valid axiomatic truths and accepting mathematics and modelling as favourable measurement, economics is rendered different from the other social sciences; it is said to be the queen. The next section deals first with the way the content of economics' own orthodoxy is defined and presents the relationship between economics and the other social sciences. Second, mathematical formalism is discussed as a basis of uniting the existing orthodoxy with finance and the position of economics facing social reality is revealed.

\subsection{Economics and Other Social Sciences}

The core of the consensus around the NNS and DSGE models is based on the idea that macroeconomics must be explained on explicit microeconomic foundations (Zouache, 2004:98). The microeconomic nature of these models allows for the presence of rational expectations and representative agents. As such, all the economic agents in the market become homogenised into Robinson Crusoes with rational expectations, which are defined to be fully consistent with the structure of the model (DSGE) used (Colander et al., 2009:256).

Whether consumers or producers, the basic aim of the agents in question in the presence of rational behaviour is to maximise utility or profit under restrictive conditions. Recognised methodological individualism is connected to this behaviour, which perceives the economic problem as one of research into effective allocation between scarce resources and infinite needs. In this way, the science of economics is reduced to the study of optimal decisions for well-specified choice problems (Colander et al., 2009:251). Thus, ontologically the economic behaviour of an abstract representative agent taken from within all social, institutional and political relationships at a level encapsulating an explanation for all human behaviour is considered an unprecedented strength (Becker, 1976:5).

Economics in the real world acquires a different character in economics from that of the other social sciences in the important measurements of the language or device used to present its microeconomic foundations. E.P.Lazear (2000:99) described the importance of this language: "Economics is not only a social science, it is a genuine science... At least during the last four decades, economics has expanded its scope of inquiry as well as its sphere of influence... the ascension of economics results from the fact that our discipline 
has a rigorous language that allows complicated concepts to be written in relatively simple, abstract terms".

The rigorous language Lazear speaks of is mathematics. P.Samuelson (1952:56) stated "Mathematics is language... In principle, mathematics cannot be worse than prose in economic theory, it certainly cannot be better than prose". As well as being a language and a means of explanation, mathematics is also seen as a vehicle of communication between economists used to inform each other about their studies (Krugman, 1998:1835). Taken in this way, G.Debreu (1986:1261) expressed his view on the use of mathematics as "...a powerful, irresistible current of thought". By their nature, elements such as optimisation and equilibrium require mathematical concepts so "...commodities, the equally large number of its prices, the multitude of its agents, and their interactions requires a mathematical model".

On the one hand, the rigorous language of economics formed through ensures a sound, hard core of internal consistency while achieving autonomy for the discipline and playing an important role in the science being qualified. On the other hand, and paradoxically, the rational behaviour of an individual abstracts him from social conditions and relationships; and by reducing economics to mathematical formalism has left the door open to a process of bowdlerisation of economics from its epistemological foundations ${ }^{5}$. M.Blaug (1997:3), criticised the level of mathematical formalism in modern economics strongly: "Modern economics is sick. Economics has increasingly become an intellectual game played for its own sake and not for its practical consequences for understanding the economic world. Economists have converted the subject into a sort of social mathematics in which analytical rigour is everything and practical relevance is nothing".

Mathematical formalism affects the relationships between economics and the other social sciences as well as the forms of those relationships. When the orthodoxy established by economics and the language used in economics are taken into account, this relationship does not involve the mutual dialogue or cooperative productive exchange that exist in disciplines such as history, sociology and political science. On the contrary, by exporting its own designed world to other worlds, the relationship follows a methodological imperialism by colonising other disciplines. J.Hirshleifer (1985:53) clearly revealed the

${ }^{5}$ If mathematics and formalism are to be used frequently in place of each other (as in this study), it is necessary to note that the contents of each are essentially different. Formalism, beyond its use in mathematics, refers to stating economic problems using specified equations and the deductive nature of method and aximatisation (Backhouse, 1998:1849). 
perceived trust of economists for their disciplines and orthodoxy: "...Economics interpenetrates them all (i.e.other social disciplines)... There is only one social science. What gives economics its imperialist invasive power is that our analytical categories-scarcity, cost, preferences, opportunities, etc. are truly universal in applicability... thus economics really does constitute the universal grammar of social science".

Such a position legitimises the tendency for mainstream economists to neglect social, cultural and institutional factors that are not modelled or expressed mathematically. This situation is also valid from the perspective of the discipline's own sociology (Dow, 2000:160). This validation comes as a result of subjects that are not being accepted as being contained in orthodoxy that are dealt with by heterodox approaches. While these approaches are excluded from mainstream economics, the relationships with other social sciences are being driven by heterodox economics. In this way, Colander et al. (2004:492) describe the possibility of dialogue with mainstream economics: "....as long as they are done with a careful understanding of the strengths of the recent orthodox approach and with a modeling methodology acceptable to the mainstream". Here it is clear that the othodoxy of an "acceptable" modelling methodology corresponds to an appropriate mathematical formalism.

\subsection{Finance, Mathematical Formalism and the Distancing of Economics from Social Problems}

As previously discussed in the context of imperial position of economics over other social sciences, scientific unification or the application of the same principles and tools to the study of phenomena from different domains is a powerful ideal in economics that significantly shapes its internal dynamics and the way it relates to the other social sciences (Marchionni, 2009: 11). In this way, the crisis can be viewed from the position of the scientific unification of mainstream economics and finance.

\subsubsection{Financialisation of Economics and the Crisis}

Since the 1970s, the area of dominance of mainstream economics has expanded greatly in accordance with the globalisation of finance. During that period, the financial markets, previously perceived as a casino in the eyes of economists, were transformed into ideal markets.

The greatest factor in this shift, as described by P. Krugman (2009), is that because both macroeconomics and financial markets are tied to rational expectations, a framework suitable to the world of Dr Pangloss in Voltaire's Candide must be accepted (Buiter, 1980: 34-50). Indeed the efficient market 
hypotheses forming the hard core of finance theory, the capital asset pricing model (CAPM) that deals with the relationship between risk and return, the Modigliani and Miller theorem and option pricing related to the Black-ScholesMerton approach conveniently overlap with the microeconomic foundations of mainstream economics. These theories form the scientific base of the activities and behaviour of economic agents in modern finance (Caldentey and Vernengo, 2010:70-73).

When we consider the world of the academic economist compared to other worlds, the world of Dr. Pangloss symbolises the best world to live in with perfect information, low transaction costs, easy entry and exit in the financial markets and the invisible hand of the market providing not only the right prices but also the right allocation of resources (Harrison, 1997:180). E.Fama (2007: 17) stated that the "...rational expectations stuff is basically efficient markets; they're pretty much the same thing. If you are talking about the macroeconomy, I don't see how you can avoid financial markets... you can't test models of market equilibrium without market efficiency because most models of market equilibrium".

The scientific unification of mainstream economics with finance, in parallel with an increase in neoliberalism, has brought finance into prominence over economics, and finance has emerged as an independent discipline. P.Harrison (1997: 182-185) stated that "...finance has become the "proving ground" for new price theory and econometric technique. This puts the field at the forefront of the technical envelope, as measured by the use of mathematics and computers". However, he also pointed out that "...we have an interesting (ongoing) tension between reality and the abstract theoretical ideal. In economics, this tension is not unique to finance, and it may well be an inevitable by-product of modeling... The neoclassical ideal... is introduced to finance with success... However, once the ideal is in place it is treated as 'truth"'.

In this way the crisis can be seen as a product of both the microeconomic foundations of neoclassical economics and of the sophisticated risk management and the asset pricing models of finance (Colander et al., 2009: 252-255; Caldentey and Vernengo: 2010: 79-80). In addition to the complicated nature of the risk management and asset pricing models used in the financial markets, newly developed financial instruments such as CDO (collateralised debt obligations) and CDS (credit default swap) and over- thecounter derivatives and the strategies supporting them made the crisis more difficult to understand and predict: those derivatives brought a structure of language and terminology into finance that could only be understood by experts. Moreover, risk management and asset pricing models showing mathematical and numerical precision brought about an illusion of control as 
the agents simply ignored the deficiencies of the models (Colander et al., 2009: 254; Lawson, 2009: 761). In other words, the agents mistook beauty for truth, choosing the internal perfection and neatness of their own mathematical models over the reality of the risk borne by the whole system.

As proof that the crisis was the product of sophisticated risk management and asset price modelling, a clear explanation for why no warnings were heeded by the system on the road to the crisis is provided by Colander et al.(2009: 250): "The implicit view behind standard equilibrium models is that markets and economies are inherently stable and that they only temporarily get off track. The majority of economists thus failed to warn about the threatening systemic crisis and ignored the work of those who did".

Beyond the problem of belief in the market mechanism, the attitude that these warnings were not seen or were ignored also implied that the warnings were not presented in appropriate language. For example, in September 2006, when N. Roubini (known as Dr. Doom) warned that a collapse in property prices would bring a serious fall in consumer confidence and lead to a recession in the American economy, he was ignored because the predictions were not substantiated by a mathematical model. Similarly, the predictions of D. Blanchflower of the Bank of England's Monetary Policy Committee that American and British economies would go into recession in the first months of 2008 did not come into effect until September 2008. Because Blanchflower's views superseded a sophisticated model, consumer confidence and public opinions on employment, contained in the evidence presented in detailed surveys were believed to have been analysed by an experienced eye (Hodgson, 2009: 1207).

In this way, the crisis contained a process whereby the resource allocation was directed away from basic social problems. As Colander et al. (2009: 264) stated, "We believe that economics has been trapped in a suboptimal equilibrium in which much of its research efforts are not directed towards the most pressing social needs".

\subsubsection{Mathematical Formalism and the Distancing of Economics from Social Problems}

Beyond failing to foresee the crisis, the passion in economics for theoretical internal consistency led to prevalent social needs being omitted from the agenda. J.E.King (2009: 395) emphasised that the basic problem of this is that compared to the theoretical model of internal consistency, the face of reality is considered a matter of secondary importance. In fact, in the words of S. W. Lewis (2007: 47-48), who contributed to the creation of the Bank of England DSGE model, this proof is clearly justified: "The pre- 
microfoundations approach puts the stress on data consistency: models that are not consistent with the data (in an econometric sense) should be rejected. In contrast, the Bank of England's new model embodies a quite diffrent approach. Internal consistency is vital, because only then can we be sure that relationships are consistent with the axioms of microeconomic theory".

The problem in that case is that rather than whether mathematical formalism has any place or not in economics, but the obsession with technique over economic and social realities (Hodgson, 2009: 1210). The 1991 Nobel Economics winner, R Coase (1999: 4), evaluated the situation in this way: "Existing economics is a theoretical system which floats in the air and which bears little relation to what actually happens in the real world". M.Friedman (1999: 137) provided a clearer emphasis: "Economics has become increasingly an arcane branch of mathematics rather than dealing with real economic problems".

In Friedman's view, even if it is accepted that mathematical formalism has a place in the failure to explain and predict the crisis, determining how to overcome that failure and eradicate the incompatability between formalism and the ontological nature of economic/social reality remains a problem.

Stressing the specific role that DSGE models played in the crisis, Colander et al. (2009: 250) looked for the problem within modelling/formalism: "Ironically, as the crisis has unfolded, economists have had no choice but to abandon their standard models and to produce handwaving common-sense remedies... It is not enough to put the existing model to one side, observing that one needs "exceptional measures for exceptional times." What we need are models capable of envisaging such "exceptional times".

Colander et al. (2009: 258-259) invited mainstream economists to consider the concept of microeconomic foundations. Once one allows for the interactions of economic agents (heterogeneity instead of representativeness) and acknowledges the importance of the contributions of areas such as behavioural and experimental economics, the reality and the explanatory power of the models increase. Indeed, developments in the sciences of neurology and psychology have shown that when individuals make decisions about their future directions and forecasts, they use existing knowledge rather than maximisation. Their cognitive capacity is limited: therefore, action is based on heuristics (Camerer, Loewenstein, Prelec, 2005: 9-64; Kahneman and Thaler, 2006: 221-234).

On the one hand, strengthening the models with realistic assumptions narrows the chasm between mathematical formalism and the real world; on the other hand, it paves the way for dialogue between the science of economics and 
other disciplines (Colander et al., 2009: 257): "What we are arguing is that as a modeling requirement, internal consistency must be complemented with external consistency: Economic modeling cannot be inconsistent with insights about real-world human behavior obtained from other branches of science".

Along with this, discussions based on mathematical formalism reveal that an understanding of the manner in which a redesign of mainstream economics models supported by realistic assumptions will be able to overcome the failure described by Colander et al. is necessary for an explanation of the crisis and adequate modelling of economic/social reality. However, the problem originates in the incompatability between the nature of mathematical formalism and the nature of economic/social reality, rather than in the type of modelling used (Lawson, 2009:762; Bigo, 2008:529). T.Lawson (2009:762) emphasises: "The fundamental problem of modern economics, as I see it, is the mainstream insistence that mathematical modelling is the only useful, and the proper, way to do economics".

In the same way as Colander et al., apart from mathematical deductive modelling per se, the framework demonstrated by Lawson was intended not for the development of a new formal model for an explanation of crisis but to discuss new methods of analysing economic/social reality based on the style of alternative dialectical procedures (Bigo, 2008:536). These new methods require an understanding of economic/social reality in the form of transforming and mutually dependent elements/actors (eg employer-worker, teacher-student), rather than consisting of isolated atomic structures (Lawson, 2009:764-765; Bigo, 2008:530).

Reaching the stage at which using models in economics or doing economics becomes the defining feature is, appropriately, shaped by both the research and publications of the discipline's internal sociology. Indeed, V.Bigo (2008:531) stated that whether dealing with the progress of economics from a scientific perspective, or from the perspective of economics is the most suitable or legitimate route, the insistence on mathematical formalism has nourished a dual hierarchic structure within academics ${ }^{6}$. The first group in this structure, those using mathematics/modelling, is formed from accepted orthodox and proper economists who are active in the field, while the other group consists of other economists with heterodox and alternative views who do not use modelling a la Lawson. M.Blaug (1998: 45) stated, "I am very pessimistic

\footnotetext{
${ }^{6}$ V.Bigo pointed out that it was possible to find the structure demonstrated in the economics profession in social life when dealing with various kinds of inequalities and explained the psychological effects of the said structure using the concept of separation anxiety.
} 
about whether we can actually pull out of this (i.e. dominance of formalism)... This is the sociology of the economics profession. We have created a monster that is very difficult to stop".

Because mathematical formalism has come to be equated with mainstream economics, it is necessary to understand it beyond the emphasis of Lawson's insistence on the mathematical formalism of mainstream economics. In fact, as V.Bigo (2008:534) stressed, this insistence reflects a concern with forecasting or prediction on a specific case. Making accurate forecasts has long been considered as the primary aim of accredited science and economists are keen to be viewed as scientists. Although he complained that much of economics has become a sub-branch of mathematics, the importance given by M.Friedman to the seperation of positive-normative economics and his methodology clearly demonstrates the desire of economics to be considered a science in the face of social realities and problems of formalism (Friedman,1966:7-8): "The ultimate goal of a positive science is the development of a 'theory' or, 'hypothesis' that yields valid and meaningful (i.e. not truistic) predictions about phenomena not yet observed... In part, it is a 'language' designed to promote 'systematic and organized methods of reasoning'... theory is to be judged by its predictive power for the class of phenomena which it is intended to "explain"”.

The roots of the understanding of economic realities through mathematical formalism can be found as in the efforts of economics to become a respectable science and economists' passion to be scientists. By abstracting economic activities from time and space and seperating them from historical and social dynamics, economics is upgraded to the level of the natural sciences and rendered universal. The structure of the discipline distances it from social problems and the other social sciences and draws the lines of research and the nature of the methods to be used so that all economists are force to remain within those borders.

\section{The Perceptions of Turkish Academicians towards the Relationship Between the Global Financial Crisis and Mainstream Economics}

The arguments discussed in the preceding sections provide a helpful guide to understanding the weaknesses of mainstream economics when it comes to forecasting and/or analysing the global financial crisis. In short, it is not possible to say that the contemporary science of economics is a valid theoretical framework for every economist; however, it can be seen that 
together, the period of neoliberalism and the rise of market economy have reinforced the dominant position of mainstream economics.

While mainstream or neoclassical economic research is a relatively broad domain, the instruction on economic theory suffers from a much narrower perspective. In this sense, a basic problem of economics education is its nearly exclusive focus on one theoretical paradigm, neoclassical economics. Both the science of economics and economic education as a part of that science are viewed as having developed under the dominance of one school of thought (neo classical) because of their lack of a pluralist structure reflecting the richness of existing theories (Denis, 2009:7-8; Ötsch and Kapeller, 2010:16).

When this is considered from the perspective of the attempt to define the implications for the future of the science of economics and its education, it is necessary to understand the relationship between the global financial crisis and mainstream economics. Based on the arguments in the preceding sections, the following section presents the factor analysis of a questionnaire administered to academicians teaching economics in Turkish universities to determine their perceptions of the relationship between mainstream economics and the crisis, revealing implications for the future of the science of economics and its education.

\subsection{Methods and Instruments}

To collect the data, a questionnaire was first prepared and all the statements to be included in the questionnaire were set by the researchers. Two main sections were created: the first section contained questions to establish the demographics (e.g., gender, title, and age) and the second section contained 25 statements directed at the aim of the study. A 5-point Likert scale was used for the responses: 1-absolutely disagree, 2-disagree, 3-undecided, 4-agree, 5absolutely agree.

The prepared questionnaire was sent by e-mail together with an explanation of the study objectives to 340 academicians (assistant professor, associate professor and professor) in the Economics and Economics and Administrative Sciences Faculties of 35 state and private universities*. The

*The universities to which questionnaires were sent are A.İ.Baysal, A.Kocatepe, Akdeniz, Anadolu, Ankara, Atatürk, Bahceşehir, Balıkesir, Bilgi, Bilkent, Çukurova, Doğuş, Dokuz Eylül, Dumlupınar, Ege, Erciyes, Galatasaray, Gazi, Hacettepe, İzmir Ekonomi, Kafkas, Karadeniz Technical, Kocaeli, Koç, Marmara, Mersin, Mugla, Middle East Technical, Sabancı, Selçuk, Süleyman Demirel, Sütçü İmam, TOBB Economy and Technology, Uludag and Yıldız Technical. 
questionnaire was administered in November 2009. After processing the data collection, 156 responses were received from a total of 340 e-mails. The required analysis of the participants' responses was performed using the SPSS 13.0 program.

The first step was the descriptive analysis (presented in Table 1 by number and percentage). The second step of the analysis was to apply factor analysis to the 25 statements and variables with a noted factor loading of more than 0.30 (Sharma, 1996:90-99; Hair et al., 1998:87-138). For the extraction of the factors, a principal components analysis was used because it is the most widely used technique; Varimax was used as the rotation technique. The third step was to perform a reliability analysis to determine the internal consistency of the obtained factors. The Cronbach Alpha $(\alpha)$ value was considered for this purpose $^{7}$. The fourth step was a correlation analysis of the relationship of the specified factors, and the fifth step was to perform $t$-tests. The sixth and final step was a general evaluation of the findings obtained from the analyses.

\subsection{Findings}

First, the descriptive statistics of the academicians who responded to the questionnaire were obtained. Gender, age, title and educational status are shown in Table 1.

${ }^{7}$ Cronbach alpha value varies between 0 and 1 in the measurement used to test the internal consistency of the variables. If the Cronbach alpha value is greater than 0.70 , the measurement has internal consistency; in other words, the measurement can be said to be reliable (Cramer, 1998:397). 
- Ankara Üniversitesi SBF Dergisi • 66-4

Table 1: Descriptive Statistics

\begin{tabular}{|c|c|c|c|c|c|}
\hline \multirow[b]{2}{*}{ Gender } & $\mathbf{n}$ & $\%$ & \multirow[b]{2}{*}{$\begin{array}{l}\text { Age Groups } \\
\text { (range } 28-67 \text { years) }\end{array}$} & \multirow[t]{2}{*}{$\mathbf{n}$} & \multirow[t]{2}{*}{$\%$} \\
\hline & & & & & \\
\hline Male & 124 & 79.5 & $28-38$ & 35 & 23.6 \\
\hline \multirow[t]{2}{*}{ Female } & 32 & 20.5 & $39-49$ & 69 & 46.6 \\
\hline & & & $50+$ & 44 & 29.7 \\
\hline \multicolumn{6}{|c|}{ Graduate Education } \\
\hline Turkey & 107 & 68.6 & Title & & \\
\hline \multirow[t]{2}{*}{ Abroad } & 49 & 31.4 & Prof. Dr. & 48 & 31,4 \\
\hline & & & Assoc. Prof.Dr. & 50 & 32,7 \\
\hline Postgraduate & & & Asst. Prof. Dr. & 55 & 35,9 \\
\hline \multicolumn{6}{|l|}{ Education } \\
\hline Turkey & 112 & 71.8 & & & \\
\hline \multirow[t]{4}{*}{ Abroad } & 44 & 28.2 & Graduate/Postgraduate & & \\
\hline & & & Education & & \\
\hline & & & Turkey & 95 & 60.9 \\
\hline & & & Abroad & 61 & 39.1 \\
\hline
\end{tabular}

It can be seen in Table 1 that of the 156 academicians, 124 (79.5\%) were male and $32(20.5 \%)$ were female, with an age range of 28 - 67 years; 35 (23.6\%) were aged between 28 and 38 years, $69(46.6 \%)$ were aged between 39 and 49 years and $44(29.7 \%)$ were aged 50 and over. Thus, it can be stated that the majority of the questionnaire participants were aged between 39 and 49 years. Of the total 156 participants, $48(31.4 \%)$ held the academic title of Professor, 50 (32.7\%) Associate Professor and 55 (35.9\%) Assistant Professor. Graduate or postgraduate education was undertaken in Turkey by $95(60.9 \%)$ participants and abroad by $61(39.1 \%)$ participants. Graduate education was undertaken in Turkey by 107 (68.6\%) participants and abroad by $49(31.4 \%)$ participants, whereas postgraduate education was undertaken in Turkey by 112 (71.8\%) and abroad by $44(28.2 \%)$. 
Metin Özdemir-Esra Güler • Is the Global Financial Crisis a Crisis of Academic Economics and its Education? 85

Table 2: Frequency Distribution of the Statements

\begin{tabular}{|c|c|c|c|c|c|c|c|c|c|c|c|c|c|}
\hline \multirow{2}{*}{ 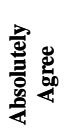 } & $0^{\circ}$ & $\underset{\infty}{+}$ & 㐫 & $\stackrel{\overbrace{}}{\simeq}$ & 王 & $\stackrel{\varrho}{\stackrel{m}{\sim}}$ & $\stackrel{2}{2}$ & $\stackrel{\infty}{\dot{m}}$ & $\stackrel{+}{\vec{N}}$ & $\stackrel{\infty}{\sim}$ & $\stackrel{\widehat{o b}}{\sigma}$ & $\hat{\underline{\theta}}$ & خे \\
\hline & $=$ & $\underline{9}$ & in & $=$ & $\approx$ & $\bar{N}$ & $\simeq$ & $a$ & m & $\simeq$ & $\approx$ & iి & m \\
\hline \multirow{2}{*}{ 离 } & $\therefore$ & f̧ & $\ddot{g}$ & $\stackrel{n}{a}$ & $\vec{\xi}$ & $\stackrel{\vec{g}}{\vec{g}}$ & $\dot{f}$ & $\begin{array}{l}\infty \\
\text { in } \\
\text { in }\end{array}$ & ชี & $\overline{0}$ & $\frac{17}{8}$ & $\begin{array}{l}\text { ¿̊. } \\
\text { în }\end{array}$ & $\frac{17}{7}$ \\
\hline & $=$ & $n$ & $\approx$ & $\widetilde{\sigma}$ & 5 & $\stackrel{2}{2}$ & $\ddot{8}$ & 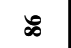 & i8 & in & 5 & 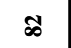 & 8 \\
\hline \multirow{2}{*}{ 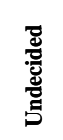 } & $\Delta^{\circ}$ & $\stackrel{\text { I }}{\mathcal{I}}$ & $\stackrel{\infty}{i}$ & $\stackrel{\check{g}}{\dot{g}}$ & $\stackrel{m}{\varrho}$ & $\stackrel{\circ}{=}$ & ن̈. & $\stackrel{m}{\dot{I}}$ & $\tilde{a}$ & $\stackrel{\sim}{=}$ & సु & $\underset{\infty}{\infty}$ & $\hat{\sigma}$ \\
\hline & $=$ & $\pi$ & $a$ & $\bar{N}$ & $\underline{\varrho}$ & $=$ & $\stackrel{\infty}{\infty}$ & $\pi$ & 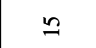 & $\bar{\lambda}$ & in & 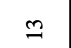 & $\simeq$ \\
\hline \multirow{2}{*}{ 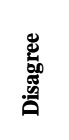 } & $\therefore$ & $\overline{\mathrm{s}}$ & $\approx$ & ల్లి & స్ & $\overrightarrow{\mathrm{C}}$ & $\overline{\vec{N}}$ & $\dddot{2}$ & ì & $\vec{m}$ & $\stackrel{n}{f}$ & $\stackrel{\infty}{\infty}$ & $\stackrel{t}{g}$ \\
\hline & $=$ & in & $\simeq$ & $\bar{n}$ & F & $\bar{m}$ & లె & లి & $\check{m}$ & $\bar{n}$ & r & సి & m \\
\hline \multirow{2}{*}{ 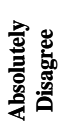 } & $0^{\circ}$ & $\vec{r}$ & $\stackrel{0}{i}$ & กู่ & $\stackrel{\infty}{\sim}$ & $\stackrel{\substack{n \\
i}}{ }$ & $\stackrel{m}{\longrightarrow}$ & $\stackrel{\sim}{+}$ & ભे & n. & ' & $\stackrel{\infty}{m}$ & $\stackrel{\bullet}{i}$ \\
\hline & $=$ & $=$ & $\sigma$ & $\infty$ & 0 & $a$ & $N$ & $r$ & 0 & 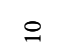 & & 6 & $\sigma$ \\
\hline \multicolumn{2}{|l|}{ 量 } & 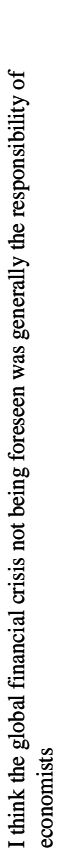 & 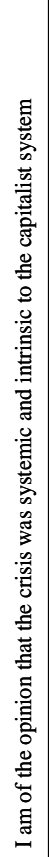 & 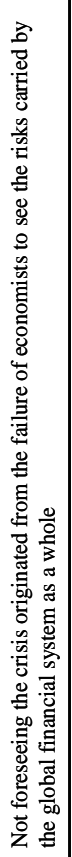 & 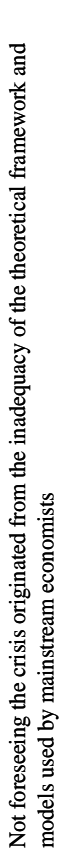 & 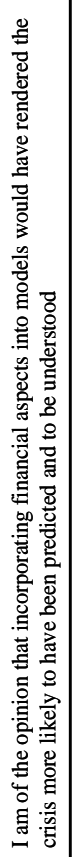 & 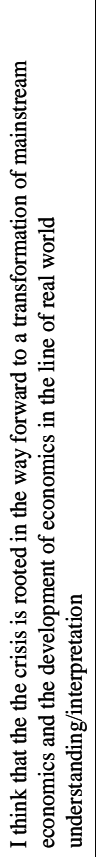 & 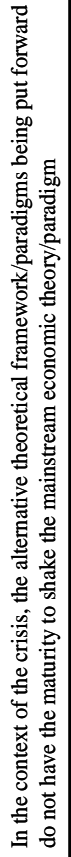 & 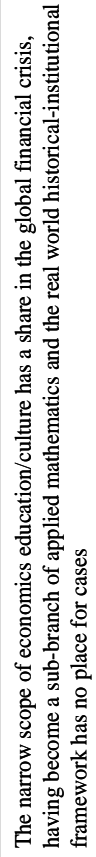 & 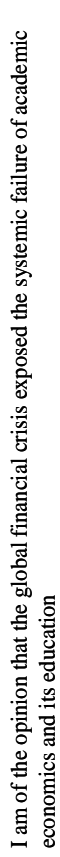 & 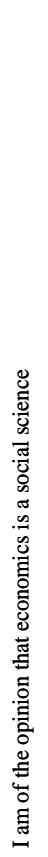 & 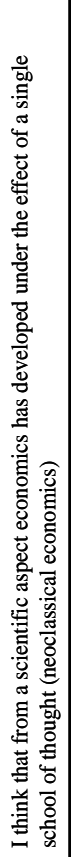 & 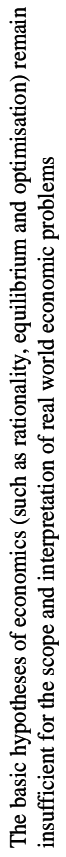 \\
\hline
\end{tabular}


86 • Ankara Üniversitesi SBF Dergisi • 66-4

\begin{tabular}{|c|c|c|c|c|c|c|c|c|c|c|c|c|}
\hline$\vec{ల}$ & 3 & $\underset{\sim}{0}$ & Iี & $\stackrel{0}{0}$ & ف् & $\stackrel{2}{I}$ & 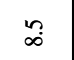 & sa & ठ̊. & $\stackrel{g}{ }$ & $\stackrel{\circ}{\circ}$ & 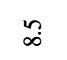 \\
\hline in & 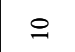 & $\sigma$ & 2 & $\cong$ & $\stackrel{1}{*}$ & $\stackrel{\sim}{\infty}$ & $\stackrel{9}{1}$ & $\simeq$ & $\bar{m}$ & $m$ & 8 & 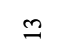 \\
\hline di & $\stackrel{8}{\dot{q}}$ & $\stackrel{\partial}{=}$ & óg & $\stackrel{\odot}{\vec{F}}$ & 年 & $\ddot{g}$ & ' & $\vec{\Delta}$ & సิ & i̊ & iे & $\vec{\Phi}$ \\
\hline 8 & I & $\stackrel{\infty}{\sim}$ & $\approx$ & \$ & $\approx$ & $\not 8$ & ' & F & 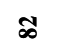 & $\sigma$ & 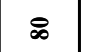 & $g$ \\
\hline 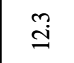 & $\stackrel{+}{2}$ & $\bar{\Xi}$ & $\bar{r}$ & $े$ & $\stackrel{\odot}{=}$ & 节 & $\Xi$ & $\stackrel{m}{\varrho}$ & $\stackrel{0}{=}$ & ले & $\vec{m}$ & $\stackrel{\square}{g}$ \\
\hline 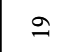 & p & $\pi$ & $=$ & $=$ & $=$ & $\exists$ & $=$ & $\stackrel{2}{2}$ & $\stackrel{\infty}{.}$ & in & 0 & ते \\
\hline$\stackrel{0}{=}$ & $\stackrel{n}{q}$ & $\hat{\dot{y}}$ & חั & में & qu & & हुं & $\frac{17}{7}$ & さે & ஜٌ & 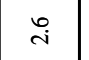 & is \\
\hline$\stackrel{\infty}{\prime}$ & $\stackrel{\infty}{m}$ & $R$ & f & : & $\stackrel{\infty}{m}$ & $\bar{m}$ & $\stackrel{\Xi}{\Xi}$ & 8 & तి & $\approx$ & $\checkmark$ & in \\
\hline$\stackrel{m}{3}$ & 2 & $\stackrel{\partial}{2}$ & de & li & $\stackrel{?}{3}$ & $\tilde{m}$ & 3 & $\infty_{\infty}^{+}$ & lo & $\dot{\vec{q}}$ & iి & 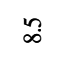 \\
\hline$\sim$ & $m$ & $\bar{m}$ & $\nabla$ & $\nabla$ & $N$ & in & 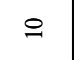 & 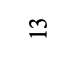 & $\sigma$ & 8 & $\nabla$ & $\simeq$ \\
\hline 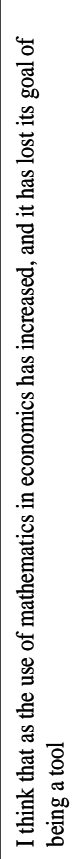 & 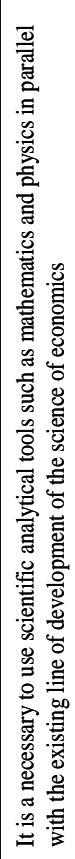 & 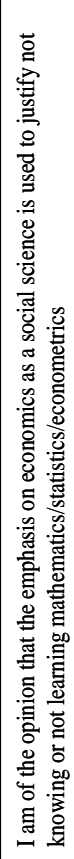 & 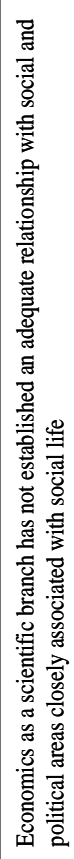 & 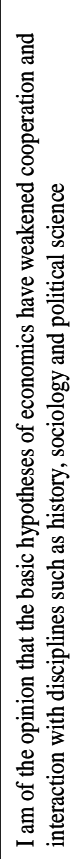 & 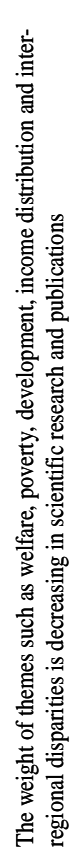 & 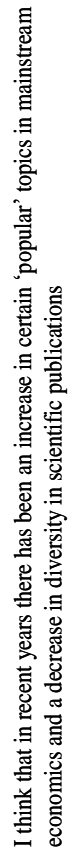 & 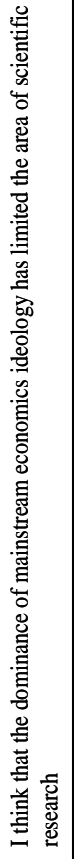 & 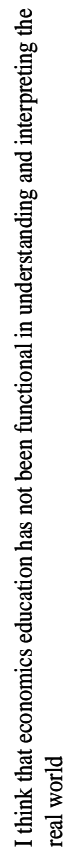 & 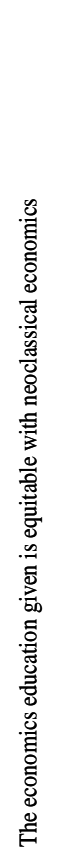 & 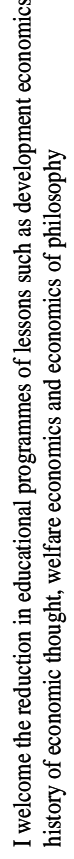 & 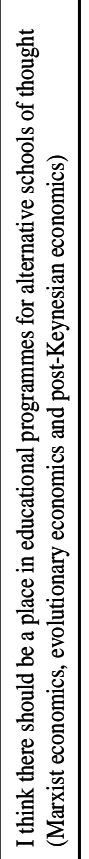 & 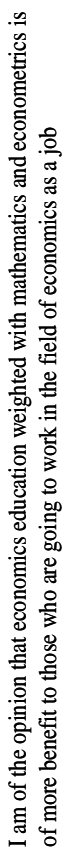 \\
\hline
\end{tabular}


Table 2 summarises the distribution frequency of the responses to the 25 statements directly related to the subject of the study. A 5- point Likert scale was used for the responses and the percentage value for each response is shown. The findings of the factor analyses are presented in Table 3. The highest factor loading related to each factor is shown in bold in the table.

Table 3: Factor Analysis Results

\begin{tabular}{|c|c|c|c|}
\hline Factors & Statements & \multicolumn{2}{|c|}{ Factor Loading } \\
\hline \multirow{7}{*}{$\begin{array}{l}\text { I. Factor: } \\
\text { The development } \\
\text { of economics } \\
\text { under the } \\
\text { dominance of a } \\
\text { single school of } \\
\text { thought }\end{array}$} & $\begin{array}{l}\text { I think that from the scientific perspective economics } \\
\text { has developed under the effect of a single school of } \\
\text { thought (neoclassical economics) }\end{array}$ & .696 & \\
\hline & $\begin{array}{l}\text { The weight of themes such as welfare, poverty, } \\
\text { development, income distribution and inter-regional } \\
\text { disparities is decreasing in scientific research and } \\
\text { publications }\end{array}$ & .683 & \\
\hline & $\begin{array}{l}\text { I think there should be a place in educational } \\
\text { programmes for alternative schools of thought (Marxist } \\
\text { economics, evolutionary economics and post-Keynesian } \\
\text { economics) }\end{array}$ & .665 & \\
\hline & $\begin{array}{l}\text { I am of the opinion that the basic hypotheses of } \\
\text { economics have weakened cooperation and interaction } \\
\text { with disciplines such as history, sociology and political } \\
\text { science }\end{array}$ & .655 & \\
\hline & $\begin{array}{l}\text { I think that economics education has not been } \\
\text { functional in understanding and interpreting the real } \\
\text { world }\end{array}$ & .629 & \\
\hline & $\begin{array}{l}\text { I think that in recent years there has been an increase in } \\
\text { certain 'popular' topics in mainstream economics and a } \\
\text { decrease in diversity in scientific publications }\end{array}$ & .628 & \\
\hline & $\begin{array}{l}\text { The basic hypotheses of economics(such as rationality, } \\
\text { equilibrium and optimisation) remain insufficient for } \\
\text { the scope and interpretation of real world economic } \\
\text { problems }\end{array}$ & .601 & \\
\hline Eigenvalue: 7.38 & $\begin{array}{l}\text { Economics as a scientific branch has not established an } \\
\text { adequate relationship with social and political areas } \\
\text { closely associated with social life }\end{array}$ & .600 & \\
\hline Explained & $\begin{array}{l}\text { The economics education given is equitable with } \\
\text { neoclassical economics }\end{array}$ & .591 & \\
\hline 19.88 & $\begin{array}{l}\text { I am of the opinion that the crisis was systemic and } \\
\text { intrinsic to the capitalist system }\end{array}$ & .514 & \\
\hline & $\begin{array}{l}\text { I think that as the use of mathematics in economics has } \\
\text { increased, and it has lost its goal of being a tool }\end{array}$ & .439 & \\
\hline
\end{tabular}




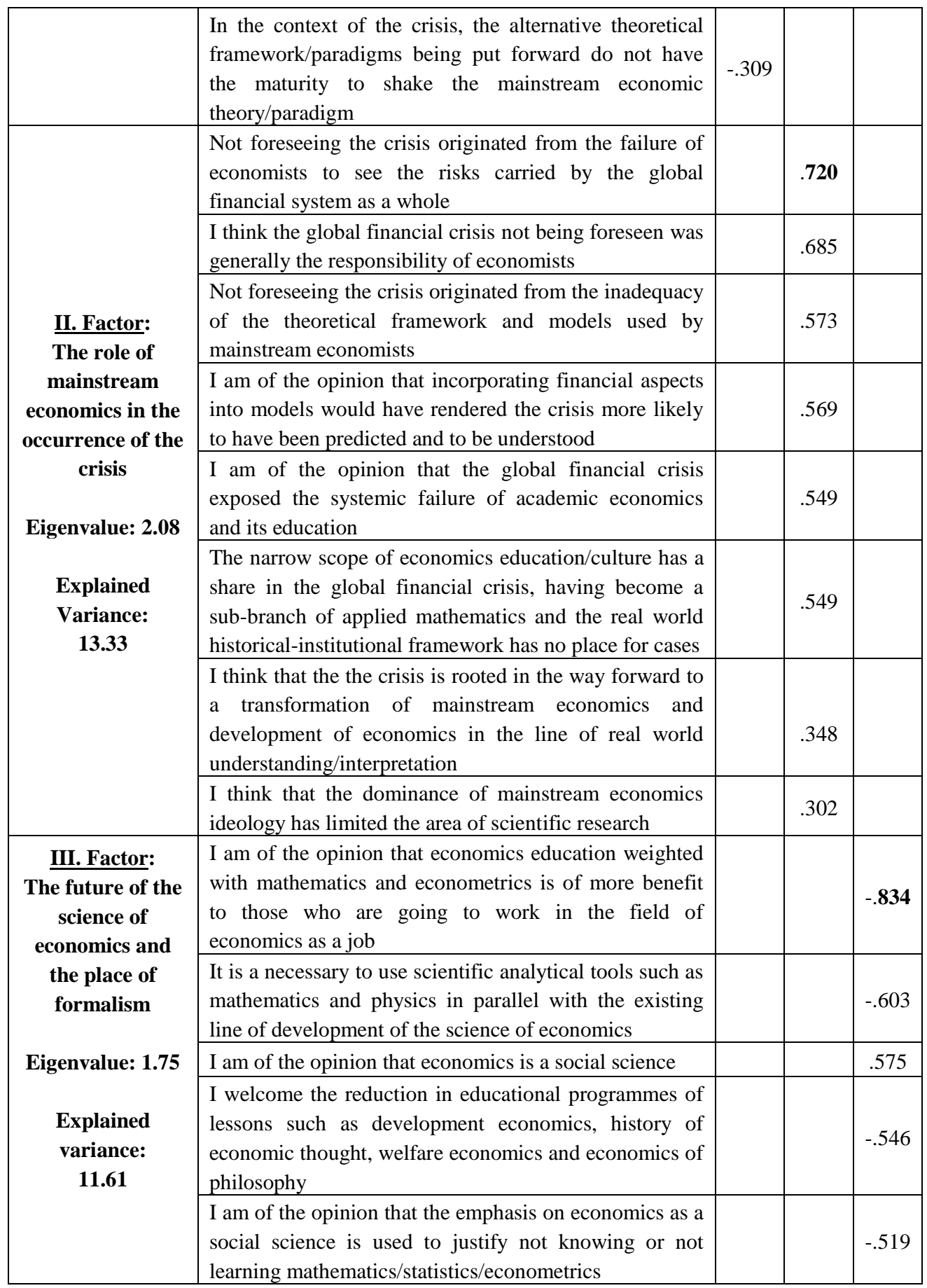


In the framework of the findings obtained by principal component analysis and the Varimax technique, an Eigen value of more than 1 is shown for 3 specified factors. When the variance relating to the factors was examined, the Explained Variance for Factor I was $19.88 \%$, for Factor II $13.33 \%$ and for Factor III $11.61 \%$, resulting in a total variance for the three factors of $44.82 \%$ $(19.88+13.33+11.61=44.82)$. Based on the Cronbach alpha values (I factor $\alpha=0.86$, II factor $\alpha=0.76$, III factor $\alpha=0.66$ ), internal consistency can be seen between the factors.

In the light of the evaluations made, the factors created in the framework of the statements and a priori information are provided in Table 3. They are described as follows: Factor I: The development of economics under the dominance of a single school of thought, Factor II: The role of classical economics in the occurence of the crisis, and Factor III: The future of the science of economics and the place of formalism.

The factor loading values expressing the correlation between factors and the statements creating the factors varied in the following ranges for each factor respectively: Factor I, 0.31 -0.70; Factor II, $0.30-0.72$; Factor III, 0.52-0.83. As all the factor loading values were 0.30 or greater, no statement was excluded.

The scores obtained as a result of the factor analysis of the aforementioned 3 factors are statistically presented in Table 4 .

Table 4: Mean ( $\bar{x})$, Standard Deviation (s), Correlation Matrix (n=156)

\begin{tabular}{ccccccc}
\hline Factors & $\begin{array}{c}\text { No of } \\
\text { items }\end{array}$ & Mean & SD & $\begin{array}{c}\text { The } \\
\text { development } \\
\text { of economics } \\
\text { under the } \\
\text { dominance of } \\
\text { a single } \\
\text { school of } \\
\text { thought }\end{array}$ & $\begin{array}{c}\text { The role of } \\
\text { mainstream } \\
\text { economics } \\
\text { in the } \\
\text { occurence of } \\
\text { the crisis }\end{array}$ & $\begin{array}{c}\text { The future of } \\
\text { the science of } \\
\text { economics and } \\
\text { the place of } \\
\text { formalism. }\end{array}$ \\
\hline $\begin{array}{c}\text { The } \\
\text { development } \\
\text { of economics } \\
\text { under the } \\
\text { dominance of a } \\
\text { single school of } \\
\text { thought }\end{array}$ & 12 & 42.35 & 8.11 & & & \\
\hline
\end{tabular}


- Ankara Üniversitesi SBF Dergisi • 66-4

\section{The role of}

mainstream

economics in

the occurence

of the crisis

The future of
the science of
economics and
the place of
formalism.
8

25.27

5.38

1

$.225^{* *}$

1

${ }^{* *} \mathrm{p}<0.01$

Table 4 shows the calculated correlations between the factors using the values related to the scores of the 3 factors. All three correlation coefficients were found to be statistically significant at a $1 \%$ significance level. Therefore, the correlation coefficient between Factor I and Factor II was $r=0.58(\mathrm{p}<0.01)$. From the scientific perspective, a strong relationship can be seen between, 'The development of economics under the dominance of a single school of thought' and 'The role of mainstream economics in the occurrence of the crisis'. The correlation coefficient between Factor I and Factor III being $r=0.34(p<0.01)$ showed a midlevel close relationship between 'The development of economics under the dominance of a single school of thought' and 'The future of the science of economics and the place of formalism'. The correlation coefficient between Factor II and Factor III being $r=0.23(\mathrm{p}<0.01)$ expressed a relationship below midlevel between 'The role of classical economics in the occurrence of the crisis' and 'The future of the science of economics and the place of formalism'.

The results of separate $t$-tests for each of the three factors to determine differences between academicians who had completed postgraduate education in Turkey and abroad are shown in Table 5. The hypotheses used for the $t$-test for each factor was

$\mathrm{H}_{0}: \mu_{1}=\mu_{2}$ (the mean points of the factor related to postgraduate education in Turkey or abroad are equal);

$\mathrm{H}_{1}: \mu_{1} \neq \mu_{2}$ (the mean points of the factor related to postgraduate education in Turkey or abroad are not equal). 
Metin Özdemir-Esra Güler • Is the Global Financial Crisis a Crisis of Academic Economics and its Education? 91

Table 5: $t$-test Results According to the Location of Postgraduate Education

\begin{tabular}{lcccc}
\hline Factors & Turkey $(\mathbf{n = 1 1 2})$ & $\begin{array}{c}\text { Abroad } \\
(\mathbf{n}=\mathbf{4 4})\end{array}$ & $\boldsymbol{t}$ & $\boldsymbol{p}$ \\
\hline $\begin{array}{l}\text { The development of economics } \\
\text { under the dominance of a single } \\
\text { school of thought }\end{array}$ & $43.16 \pm 7.91$ & $39.54 \pm 7.93$ & 2.567 & $\mathbf{. 0 1 1}$ \\
$\begin{array}{l}\text { The role of mainstream } \\
\text { economics in the occurrence of } \\
\text { the crisis }\end{array}$ & $25.44 \pm 5.57$ & $23.36 \pm 5.54$ & 2.097 & $\mathbf{. 0 3 9}$ \\
$\begin{array}{l}\text { The future of the science of } \\
\text { economics and the place of } \\
\text { formalism. }\end{array}$ & $18.32 \pm 3.18$ & $16.68 \pm 3.02$ & 2.937 & $\mathbf{. 0 0 4}$ \\
\hline
\end{tabular}

When considering whether there was a difference in opinion between academicians who had completed their postgraduate education in Turkey or abroad the $\mathrm{H}_{0}$ hypothesis was rejected because the $\mathrm{p}$ value was below the $5 \%$ significance level in each of the three factors (Factor I, 0.011<0.05; Factor II, $0.039<0.05$; Factor III $0.004<0.05$ ). This showed that for all three factors, the factor scores were not equal for the different locations of postgraduate education. Therefore, when considering only the location of postgraduate education, those who had studied in Turkey were seen to have a higher level of agreement than those who had studied abroad with the development of economics under the dominance of a single school of thought and the role of mainstream economics in the occurrence of the crisis, as well as protecting the importance of formalism in the future of the science of economics.

\subsection{General Evaluation}

The perceptions of the relationship between global financial crisis and mainstream economics of academicians teaching economics in Turkish universities were considered using factor analysis. The results of the analysis determined 'the development of economics under the dominance of a single school of thought' to be the strongest factor in explaining the perceptions of academicians of the relationship between the crisis and mainstream economics. The next strongest were the factors expressing that mainstream economics had played a role in the occurrence of the crisis and the protection of the importance of formalism in the future of the science of economics. 
Taking factor loading into consideration, this statistical analysis reveals the academicians' perception of a strong relationship between the development of economics under the dominance of a single school of thought and the role of mainstream economics in the occurrence of the crisis. A difference was also observed in all three factors between the academicians who completed their postgraduate education in Turkey or abroad. Those who had taken postgraduate degrees in Turkey had a higher level of agreement than those who had studied abroad with the development of economics under the dominance of a single school of thought, mainstream economics had played an important role in the occurrence of the crisis and the protection of the importance of formalism in the future of the science of economics.

In addition to the findings obtained above, Table 6 shows the differences in replies between academicians who undertook postgraduate education in Turkey or abroad, to four statements, which were chosen in order to reveal the implications of the relationship between economics and the future of its education.

When the data in Table 6 are examined, it can be seen that academicians who undertook postgraduate education both in Turkey and abroad have a high level of agreement with the first statement that the existing orthodoxy of economic theory remains insufficient for the scope and interpretation of real world economic problems (Turkey-agree $41.10 \%+$ absolutely agree $30.50 \%=71.60 \%$; abroad-agree $50.0 \%+$ absolutely agree $13.30 \%=63.30 \%$ ).

Despite complaints directed at the existing orthodoxy, it can be observed that the two groups think differently, as demonstrated in the answers to the second statement that the crisis revealed the systemic failure of academic economics and its education. While the level of disagreement was $49.2 \%$ (disagree $42.6 \%+$ absolutely disagree $6.6 \%$ ) from those who postgraduate education was obtained abroad, $33.4 \%$ (disagree $26.9 \%+$ absolutely disagree $6.5 \%$ ) of those from Turkey disagreed. These results demonstrate that the location of postgraduate education changes the nature of the perceptions of the relationship between the crisis and mainstream economics.

The accumulated theoretical literature and experience obtained from previous crises shows that depressions can be overcome by the internalisation of criticisms levelled at mainstream economics. In the present crisis, questions are being asked about whether the current dominance of mainstream economics will be protected or not in the near future. In response to the third statement in Table 6 regarding whether mainstream economics and models allowing for financial aspects would it enable potential crises to be foreseen, both groups of academicians have a high level of agreement (Turkey-agree $48.4 \%+$ absolutely agree $15.1 \%=63.5 \%$; abroad-agree $50.8 \%$ +absolutely agree $11.9 \%=62.7 \%$ ). 
Metin Özdemir-Esra Güler • Is the Global Financial Crisis a Crisis of Academic Economics and its Education? 93

Taking the development of the nature of microeconomic foundations as the basis of orthodoxy a la Colander et al. (2009), it is possible to conclude that the academicians' opinions regarding the progress of the development of the grasp of the science of economics on social reality were realised.

Dependent on this, in response to the fourth statement in Table 6, the two groups can be viewed as having significantly different views. The statement that economics has become a sub-branch of applied mathematics and does not allow other accepted approaches within the discipline or cooperation and dialogue with other disciplines and that economics education played a role in the crisis had an agreement response level of agreement of $47.5 \%$ (agree $34.4 \%+$ absolutely agree $13.1 \%$ ) from those who undertook postgraduate education abroad and 74.2\% (agree $47.3 \%+$ absolutely agree $26.9 \%$ ) from those who remained in Turkey. 
94 • Ankara Üniversitesi SBF Dergisi • 66-4

Table 6: The Frequency Distribution of Various Statements

\begin{tabular}{|c|c|c|c|c|c|c|}
\hline & \multirow{2}{*}{ 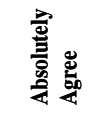 } & $\therefore$ & $\stackrel{3}{9}$ & $\stackrel{m}{m}$ & $\stackrel{n}{=}$ & $\vec{\Xi}$ \\
\hline & & $=$ & $\infty$ & $N$ & r & $\infty$ \\
\hline \multirow{8}{*}{ 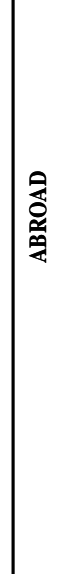 } & \multirow{2}{*}{ 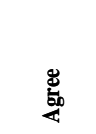 } & $\therefore$ & 옹 & ڤั่ & $\stackrel{\infty}{\stackrel{\leftrightarrow}{0}}$ & 芦 \\
\hline & & $=$ & లి & $\stackrel{\infty}{\infty}$ & $\vec{m}$ & $\vec{\sim}$ \\
\hline & \multirow{2}{*}{ 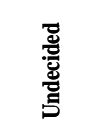 } & $\therefore$ & $\stackrel{i}{i}$ & $\stackrel{\circ}{\infty}$ & $\stackrel{n}{=}$ & 苞 \\
\hline & & $=$ & $m$ & $=$ & $r$ & 으 \\
\hline & \multirow{2}{*}{ 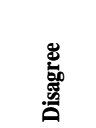 } & $\therefore$ & ㅇ.ల. & 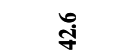 & $\stackrel{\infty}{\simeq}$ & 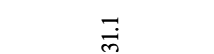 \\
\hline & & $=$ & $\stackrel{\infty}{-}$ & $\stackrel{i}{ }$ & $=$ & $\stackrel{2}{ }$ \\
\hline & \multirow{2}{*}{ 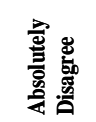 } & $\therefore$ & 9 & రొ & $\tilde{\infty}$ & $\stackrel{\leftrightarrow}{+}$ \\
\hline & & $=$ & - & $\nabla$ & $n$ & $m$ \\
\hline \multirow{10}{*}{ 裵 } & \multirow{2}{*}{ 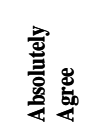 } & $\therefore$ & 胥 & $\stackrel{\infty}{\Theta}$ & $\bar{n}$ & छें \\
\hline & & $=$ & శి & 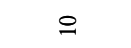 & \pm & $\mathscr{\sim}$ \\
\hline & \multirow{2}{*}{ 离 } & $\therefore$ & $\vec{F}$ & $\stackrel{\phi}{\infty}$ & 市 & $\frac{3}{q}$ \\
\hline & & $=$ & के & ల & ケ & 寸 \\
\hline & \multirow{2}{*}{ 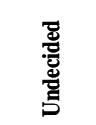 } & $\therefore$ & 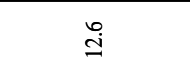 & $\stackrel{\cong}{I}$ & $\stackrel{\infty}{\varrho}$ & $\stackrel{+}{i}$ \\
\hline & & $=$ & $\simeq$ & $\stackrel{0}{0}$ & 으 & in \\
\hline & \multirow{2}{*}{ 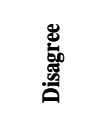 } & $\therefore$ & $\stackrel{\circlearrowright}{\mathrm{I}}$ & ఫે & $\frac{n}{n}$ & $\stackrel{\Upsilon}{\cong}$ \\
\hline & & $=$ & $-N$ & Nin & No & -0 \\
\hline & \multirow{2}{*}{ 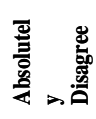 } & $\therefore$ & $\tilde{m}$ & 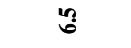 & $\stackrel{?}{+}$ & $\tilde{m}$ \\
\hline & & $=$ & $m$ & 0 & $\sigma$ & $m$ \\
\hline & 至 & & 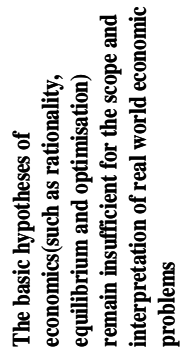 & 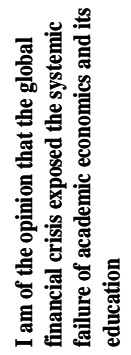 & 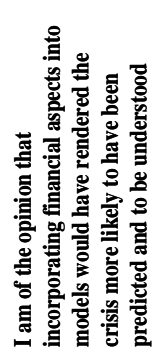 & 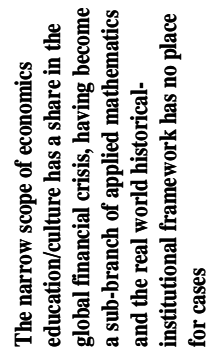 \\
\hline
\end{tabular}


In addition to this, the high rate of the 'Undecided' (16.4\%) responses to the fourth statement by those who undertook postgraduate education abroad reflects their perceptions of the confusion and uncertainty of the relationship between the current position of economics education and its future. Because formalism has come to be a defined characteristic of economics, the quandary whitin economics education is whether the dominance of the formal techniques of economics education will be determined by economists weighted towards the attributes of a technician or engineer or by intellectually equipped economists who know and understand the economic and social problems of the real world ${ }^{8}$.

In the light of these findings and when we recall the previously considered problems of defining economic/social reality and the significance of the shift toward mathematical formalism, the picture of the science of economics and the economics profession is clearly revealed in this statement by A.Rubinstein (1995:12): "The issue of interpreting economic theory is... the most serious problem now facing economic theorists. The feeling among many of us can be summarized as follows. Economic theory should deal with real world. It is not a branch of abstract mathematics even though it utilizes mathematical tools. Predictions from economic theory are not nearly as accurate as those offered by the natural sciences and the link between economic theory and practical problems... is tenous at best... Economic theory lacks a consensus as to its purpose and interpretation. Again and again, we find ourselves asking the question "where does it lead"".

\section{Conclusion}

While the global financial crisis has inspired considerable debate concerning economic policy, the discussion of its effects on economics as an academic discipline and the education of economists has been neglected. Using a questionnaire administered to academicians teaching economics in Turkish universities, this paper explores the relationship between the global financial crisis, mainstream economics and the future of economics education.

${ }^{8}$ C.Goodhart (2009b:15) made this ironic statement about the crisis, including the typology of both economists: "One of the lessons of the recent crisis, ....is, hire fewer mathematicians and physicists who build models on the basis of data that they can observe over a relatively short period, and hire a few more historians who know what can go wrong even if they don't necessarily have a good data basis to put into particular models". 
Our analysis provides several results. First, the academicians teaching economics in Turkish universities are of the opinion that mainstream economics played an important role in the occurrence of the crisis due to the science of economics having developed under the dominance of a single school of thought. Second, consistent with Colander et al.(2009), many economists believe that by means of the development of the microeconomic nature of the models used, the crisis of mainstream economic theory will be able to be overcome, protecting the importance of mathematical formalism in the future.

However consistent with Lawson (2009), when the previously considered problems of defining economic/social reality and the significance of the shift toward mathematical formalism are recalled, some academicians believe that economics has become estranged from social problems and its relationships with the other social sciences are limited. This situation reveals itself among academicians in their perception of confusion and uncertainty regarding the identity and makeup of the economist and especially of the future of economics education after the crisis.

Our study reveals that it is necessary to develop more realistic models to be used in economics and to establish a more productive relationship with other social sciences such as history, sociology and politics. This development requires a framework for economics education with a more pluralistic orientation that allows for different theoretical frameworks.

\section{Kaynakça}

Arestis, P. (2007), "What is the New Consensus in Macroeconomics", P. Arestis (Ed.), Is There a New Consensus in Macroeconomics? (USA: Palgrave Macmillan).

Backhouse, R.E. (1998), "If Mathematics is Informal, Then Perhaps We Should Accept That Economics Must be Informal Too", The Economic Journal, 108(451): 1848-1858. doi: 10.1111/1468-0297.00380.

Becker, G.S. (1976), The Economic Approach to Human Behavior, (USA: Chicago University Press).

Bernanke, B. S. (2004), "The Great Moderation", Remarks by Governor Ben S. Bernanke At the Meetings of the Eastern Economic Association, Retrieved 2009, March 25, from http://www.federalreserve.gov/boarddocs/speeches/2004/20040220/default.htm

Bigo, V. (2008), "Explaining Modern Economics (as a microcosm of society)", Cambridge Journal of Economics, 32(4), 527-554. doi:10.1093/cje/bem058. 
Metin Özdemir-Esra Güler • Is the Global Financial Crisis a Crisis of Academic Economics and its Education? 97

Blanchard, O. (2009), "The State of Macro", Annual Review of Economics, 1(1): 209-228. doi:10.1146/annurev.economics.050708.142952.

Blanchflower, D. (2009), "The Future of Monetary Policy", Retrieved 2009, March 25, from http://www.bankofengland.co.uk/publications/speeches/2009/speech382.pdf.

Blaug, M. (1997), "Ugly Currents in Modern Economics", Options Politiques, Septembre, 3-8. Retrieved 2009, April 20, from http://www.irpp.org/po/archive/sep97/blaug.pdf.

Blaug, M. (1998), “The problems with formalism: interview with Mark Blaug”, Challenge, 41 (3): 3545.

Buiter, W. (2009), "The Unfortunate Uselessness of most 'state of the art'Academic Monetary Economics", Retrieved 2009, March 04, from http://blogs.ft.com/maverecon/2009/03/the-unfortunate-uselessness-of-most-state-ofthe-art-academic-monetary-economics/.

Buiter, W. H. (1980), "The Macroeconomics of Dr. Pangloss A Critical Survey of the New Classical Macroeconomics", The Economic Journal, 90 (357): 34-50.

Caldentey, E.P. and M. Vernengo (2010), "Modern Finance, Methodology and Global Crisis", Real World Economics Review, 52: 69-81, Retrieved 2010, March 10, from www.paecon.net/PAEReview/issue52/CaldenteyVernengo52.pdf.

Camerer, C., G. Loewenstein, D. Prelec (2005), "Neuroeconomics: How Neuroscience Can Inform Economics", Journal of Economic Literature, 63(1): 9-64.

Clarida, R., J. Gali, M. Getrler (1999), "The Science of Monetary Policy: A New Keynesian Perspective", Journal of Economic Literature, 37(4): 1661-1707.

Coase, R.H. (1999), "An Interview with Ronald Coase", ISNIE (International Society for New Institutional Economics Newsletter), 2(1): 3-10, Retrieved 2009, April 20, from http://www.isnie.org/assets/files/newsletters/NL6.pdf.

Colander, D., M. Goldberg, A. Haas, K. Juselius, A. Kirman, T. Lux, B. Sloth (2009), "The Financial Crisis and the Systemic Failure of the Economics Profession", Critical Review, 21(2\&39): 249-267. pdfserve.informaworld.com/428992_758064766_713997792.pdf

Colander, D., R. P. F. Holt, J. B. Rosser, (2004), "The Changing Face of Mainstream Economics", Review of Political Economy, 16(4): 485-499. pdfserve.informaworld.com/428992_758064766_713997792.pdf.

Cramer, D. (1998), Fundamental Statistics for Social Research, (New York: Routledge).

Debreu, G. (1986), "Theoretic Models: Mathematical Form and Economic Content", Econometrica, 54(6): 1259-1270.

Denis, A. (2009), "Editorial: Pluralism in Economics Education", The International Review of Economics Education, 8(2): 7-22, Retrieved 2009, December 23, from http://www.economicsnetwork.ac.uk/iree/v8n2/editorial.pdf. 
Dow, S.C. (2000), "Prospects for the Progress of Heterodox Economics", Journal of the History of Economic Thought, 22(2): 157-170. doi: 10.1080/10427710050025367.

Dumenil, G. and D.Levy (2011), Crisis of Neoliberalism, (USA: Harvard University Press).

Eichengreen, B. (2009), "The Last Temptation of Risk", The National Interest, May/June 2009, Retrieved 2009, June 14, from http://www.nationalinterest.org/Article.aspx?id=21274.

Fama, E. F. (2007), "Interview with Eugene Fama”, The Region, 15-22, Retrieved 2009, August 2010, from http://www.minneapolisfed.org/.

Foster, J.B. and F.Magdoff (2009), The Great Financial Crisis, Causes and Consequences, (USA: Monthly Review Press).

Friedman, M. (1966), The Methodology of Positive Economics. Essays in Positive Economics, (Chicago: University of Chicago Press).

Friedman, M. (1999), Conversation with Milton Friedman, B. Snowdon and H.R. Vane (Eds), Conversations with Leading Economists: Interpreting Modern Macroeconomics, (UK: Edward Elgar).

Goodfriend, M. (2002), "Monetary Policy in the New Neoclassical Synthesis: A Primer", International Finance, 5(2): 165-191. doi: 10.1111/1468-2362.00093/pdf.

Goodfriend, M. (2007)," How the World Achieved Consensus on Monetary Policy", Journal of Economic Perspectives, 21(4): 47-68. doi:10.1257/jep.21.4.47.

Goodhart, C.A.E. (2009a), "The Continuing Muddles of Monetary Theory: A Steadfast Refusal to Face Facts”, Economica, 76(1): 821-830. doi: 10.1111/j.1468-0335.2009.00790.x.

Goodhart, C. (2009b), "The Financial Crisis and the Future of the Financial System", Zeszyty BRE Bank-CASE Seminar, 100, Retrieved 2009, December 20, from http://www.case.com.pl/upload/publikacja_plik/27152003_100.pdf.

Grauwe, P. De (2007), "Cherished myths have fallen victim to economic reality", Financial Times, July 23, Retrieved 2009, June 2009 from http://www.econ.kuleuven.ac.be/ew/academic/intecon/degrauwe.

Hair J., R. Anderson, R. Tatham, W. Black (1998), Multivariate Data Analysis, (USA: Prentice-Hall, Inc.).

Harrison, P. (1997), "A History of an Intellectual Arbitrage: The Evolution of Financial Economics", History of Political Economy, 29(3):172-187.

Hirshleifer, J. (1985), "Expanding Domain of Economics", The American Economic Review, 75(6): 53-68.

Hodgson, G.M. (2009), "The Great Crash of 2008 and the Reform of 2008", Cambridge Journal of Economics, 33(6): 1205-1221. doi:10.1093/cje/bep050. 
Metin Özdemir-Esra Güler • Is the Global Financial Crisis a Crisis of Academic Economics and its Education? 99

Kahneman, D. and R.Thaler (2006), "Anomalies: Utility Maximization and Experienced Utility", Journal of Economic Perspectives, 20(1): 221-234. doi: $10.1257 / 089533006776526076$

Keynes, J.M. (1936), The General Theory of Employment, Interest and Money, (London: MacMillan).

King, J.E. (2009), "Economists and the Global Financial Crisis", Global Change, Peace and Security, 21(3): 389-396. http://pdfserve.informaworld.com/891408_758064766_915111943.pdf.

Kocherlakota, N. (2009), "Modern Macroeconomic Models as Tools for Economic Policy,", Region, ol.24, No.1: 5-21.

Krugman, P. (1998), "Two Cheers for Formalism”, The Economic Journal, 108(451), November: 1829-1836. doi: 10.1111/1468-0297.00378.

Krugman, P. (2009), "How Did Economists Get it So Wrong?", New York Times, September 2, Retrieved 2009, September $10, \quad$ from http://www.nytimes.com/2009/09/06/magazine/06Economic-t.html.

Lawson, T. (2009), "The Current Economic Crisis: Its Nature and the Course of Academic Economics", Cambridge Journal of Economics, 33(4): 759-777. doi:10.1093/cje/bep035.

Lazear, E.P. (2000), “Economic Imperialism”, Quarterly Journal of Economics, 115(1): 99-146.

Lewis-Wren, S. (2007), Arethere Dangers in the Microfoundations Consensus?. Philip Arestis (Ed.), Is There a New Consensus in Macroeconomics?, (USA: Palgrave Macmillan).

Lucas, R.E. (1995), "Monetary Neutrality", Lecture to the memory of Alfred Nobel December 7, 1995, Retrieved 2009, April 10, from http://nobelprize.org/nobel_prizes/economics/laureates/1995/lucas-lecture.pdf.

Lucas, R.E. (2004), “Keynote Address to the 2003 HOPE Conference: My Keynesian Education", History of Political Economy, 36, Annual Supplement: 12-24.

Mankiw, N.G. (2006), "The Macroeconomist as Scientist and Engineer", Journal of Economic Perspectives, 20(4): 29-46. doi: 10.1257/jep.20.4.29.

Marchionni, C. (2009), "Scientific Unification in Economics The case of the New Economic Geography”, Humana Mente, 10, 11- 24, Retrieved 2009, August 10, from http://www.humanamente.eu/PDF/Paper_Marchionni_Scientific_Unification_in\%20_Ec onomics_issue_10.pdf.

Ötsch, Otto-Kapeller, J. (2010), "Perpetuating the Failure:Economic Education and the Current Crisis", Journal of Social Science Education, Vol.9, No:2: 16-25.

Rubinstein, A. (1995), “John Nash: The Master of Economic Modelling”, Scandinavian Journal of Economics, 97(1): 9-13. 
100 • Ankara Üniversitesi SBF Dergisi • 66-4

Samuelson, P.A. (1952), "Economic Theory and Mathematics: An Appraisal", The American Economic Review, 42(2): 56-69.

Sharma, S. (1996), Applied Multivariate Technique, (New York: John Wiley \& Sons).

Spaventa, L. (2009), “Economists and Economics: What Does the Crisis Tell Us?”, CEPR Policy Insight, 38, Retrieved 2009, August 10, from http://www.cepr.org/pubs/policyinsights/Policylnsight38.pdf.

Stock, J.H.and Watson, M.W. (2003), "Has the Business Cycle Changed: Evidence and Explanations", Monetary Policy and Uncertainty: Adopting to a Changing Economy, Federal Reserve Bank of Kansas City Symposium, Jackson Hole.

TEK (1993), 2000’li Yıllarda Türkiye Ekonomisi ve Ekonomi Öğretimi, (Ankara, Türkiye Ekonomi Kurumu).

Tovar, C.E. (2008), "DSGE Models and Central Banks",(Bank for International Settlements, Working Paper No.258). Retrieved 2008, September 26, from http://www.bis.org.

TÜBA (2007), İktisat Öngörü Çalışması 2003-2023, Rapor No.17, (Ankara, Türkiye Bilimler Akademisi).

Uygur, Ercan (Ed.) (2005), İktisat Eğitimi, (Ankara, Türkiye Ekonomi Kurumu).

Zouache, A. (2004), "Towards a New Neoclassical Synthesis? An Analysis of the Methodological Convergence Between New Keynesian Economics and Real Business Cycle Theory", History of Economic Ideas, 12(1): 95-117. 